Original research article

\title{
Gender differentials in internal migration decisions: the case of Dilla Town, Southern Ethiopia
}

\author{
Million Yilma ${ }^{1}$, Nigatu Regassa ${ }^{2}$ * \\ ${ }^{1}$ Hawassa University, College of Education, Ethiopia \\ ${ }^{2}$ University of Saskatchewan, School of Public Health, Saskatoon, Canada
}

\section{Abstract}

Introduction: Internal migration has become an increasingly important socioeconomic phenomenon in Ethiopia as the country has been passing through new economic and social order since the year 1991. This study was primarily aimed at examining the gender differentials in migration decisions based on data collected from a town in Southern Ethiopia.

Methods: The study used data collected from 216 randomly selected households from three sub-cities of Dilla Town. Both bivariate (chi-square) and multivariate analysis (logistic regression) were used to examine the gender differentials in migration decisions.

Results: The analysis showed the importance of gender differences in migration decisions; that migration is gender and age selective $(p<0.05)$. More females than males make planned migration decisions $(p<0.001)$. While males migrate mainly due to economic issues, females tend to migrate more due to familial issues $(p<0.001)$. More females opt to migrate for education while more males move for business. Female migrants appeared to have more positive impacts on their households at the place of origin through remittance. In the multivariate analysis, three factors appeared to have significant association with frequency of remittance $(p<0.05)$ : regular communication, employment status and income.

Conclusions: The intention and decision of male and female migrants differs significantly; females tend to make a more planned migration involving household decision. The study suggests the need for in-depth investigation of the positive impacts of migration sex-age selective migration on the place of origin.
\end{abstract}

Keywords: Determinants; Differentials; Gender; Migration; Remittance

\section{Introduction}

Migration has become an important topic in the global arena requiring strategic as well as policy attention (Muru, 2008; Peri, 2016). Migration is a highly selective process and who is more likely to migrate depends upon a number of factors including individual characteristics and "push" and "pull" factors at the place of origin and the destination (Cattaneo, 2007). The current discourse on migration has failed to adequately address gender-specific migration experiences, even though women constitute an overwhelming majority of migrants. A gender perspective on migration is imperative, since women have significantly different migration motivations, patterns, options and obstacles from men (UNICEF, 2017).

In Africa, internal migration is far more significant for development in terms of the numbers of people moving and their poverty reduction potential and well-being outcomes (Awumbila, 2015). Today's migration can be empowering for men and women, allowing women to access employment and education, improve gender equality and norms, strengthen agency, and offer them the ability to make independent decisions to achieve desired outcomes (Awumbila, 2015; Cattaneo,
2007). The growing cities in Africa provide opportunities for migrants to create a livelihood, engage in entrepreneurship, and accumulate assets, thus contributing to human capital development (Awumbila, 2017). Conversely, migration may also exacerbate vulnerabilities, including abuse and trafficking, particularly when migrants are low skilled (IOM, 2013; O’Neil et al., 2016).

The tide of migration to urban areas is mainly triggered by "push" factors (IOM, 2013; Lattes, 1989; McBride, 1991; Tacoli et al., 2015; United Nations, 1984). It is generally believed that most decisions to migrate are made in response to a combination of economic, social and political pressures and incentives. Displacement disproportionately disadvantages women, because it results in reduced access to resources to cope with household responsibility and increased physical and emotional violence (El Jack 2003; UNICEF, 2017). In some instances, inequalities within and between localities create incentives to move (Jolly and Reeves, 2005). The ongoing gender relations and hierarchies within the household context also affect such decisions - the interests of women and men do not necessarily coincide and may affect decisions about who manages to migrate, for how long, and where to migrate (Boyd and Grieco, 2003; Deshingkar, 2005).

\footnotetext{
* Author for correspondence: Nigatu Regassa, University of Saskatchewan, School of Public Health, 104 Clinic Place, Saskatoon, SK, S7N 2Z4, Canada; e-mail: negyon@yahoo.com

http://doi.org/10.32725/kont.2019.026

Submitted: 2018-09-14 • Accepted: 2019-03-20 • Prepublished online: 2019-04-26

KONTAKT 21/3: 312-319 • EISSN 1804-7122 • ISSN 1212-4117

(c) 2019 The Authors. Published by University of South Bohemia in České Budějovice, Faculty of Health and Social Sciences.

This is an open access article under the CC BY-NC-ND license.
} 
During the last three decades, the huge gender disparities in the migration process have been recognised, as have the opportunities and challenges (Camlin et al., 2013). There are significant differences between men and women in terms of motivations, risks, and norms governing and promoting their movement and assimilation, as well as differential consequences (O'Neil et al., 2016; Camlin et al., 2013; Curran and Saguy, 1997). A study in Thailand (De Jong et al., 1996) and in Mexico (Donato, 1993) suggested that most differences in migration experienced between men and women reflect their differences in socialization, and socio-cultural values. In line with this, Omelaniuk (2005) noted that gender as a social construction which organizes relations between males and females can greatly differentiate the causes, processes, characterizations and impacts (challenges and opportunities) of migration between the two sexes.

Migration could be either an individual or family decision. The neoclassical microeconomic theory of migration decision-making associates migration with individual choice; whereby the rational actor is motivated to move to maximize one's own personal gains (Massey, 1998; Todaro, 1976). In contrast, the new household economic theory places migration decisions within the context of the household and contends that the family is at the center of migration decision-making. Knowing how these differences play-out at the interface of migration can be important from a variety of angles.

Ethiopia, as one of the most populous countries in Afri$\mathrm{ca}$, is also subject to both internal and international migration in different forms. The number and composition of migration in the country has shown a lot of changes over the last three decades. In this regard, Fransen and Kushminder (2009) noted that Ethiopia has known many types of migration over the years due to a variety of reasons, including political instability, war, famine, and economic hardship over the course of its history. It is noted in general that the development of Ethiopian towns exhibited the migration of various categories of people who came to resettle as trade migrants, civil servants, soldiers, construction workers and domestic workers (Fransen and Kushminder, 2009; Tadele et al., 2006). The country has been undergoing a major transformation from a centrally planned to a market-oriented economy since the current government came to power in 1991. Under such transformations, internal migration tends to play an increasing role both demographically and economically (Ezra and Kiros, 2001). In most parts of the country, migration is increasingly becoming a common phenomenon as a direct response to different problems faced or for the seeking of better opportunities at the new destination (Ezra and Kiros, 2001; Morrissey, 2007). In Ethiopia, both females and males migrate to small and big towns (Gurmu, 2005; Regassa and Yusufe, 2011; World Bank, 2011) due to various interwoven socio-economic and ecological factors.

The study area, Dilla town, is one of the growing urban centers receiving an influx of migrants from different parts of the country. It is the administrative center of the Gedeo Zone in the Southern Nations, Nationalities, and Peoples Region (SNNPR). It is located on the main road from Addis Ababa to Nairobi and is an important trade center (especially for coffee). Despite the increasing numbers of internal migrants in the region and their gendered implications, very few studies have focused on how gender differentials operate to influence the causes, processes and impacts of migration at the place of destination and origin. Understanding these dynamics has important implications since demographic selection in migration implies the redistribution of population both at the place of origin and destination.

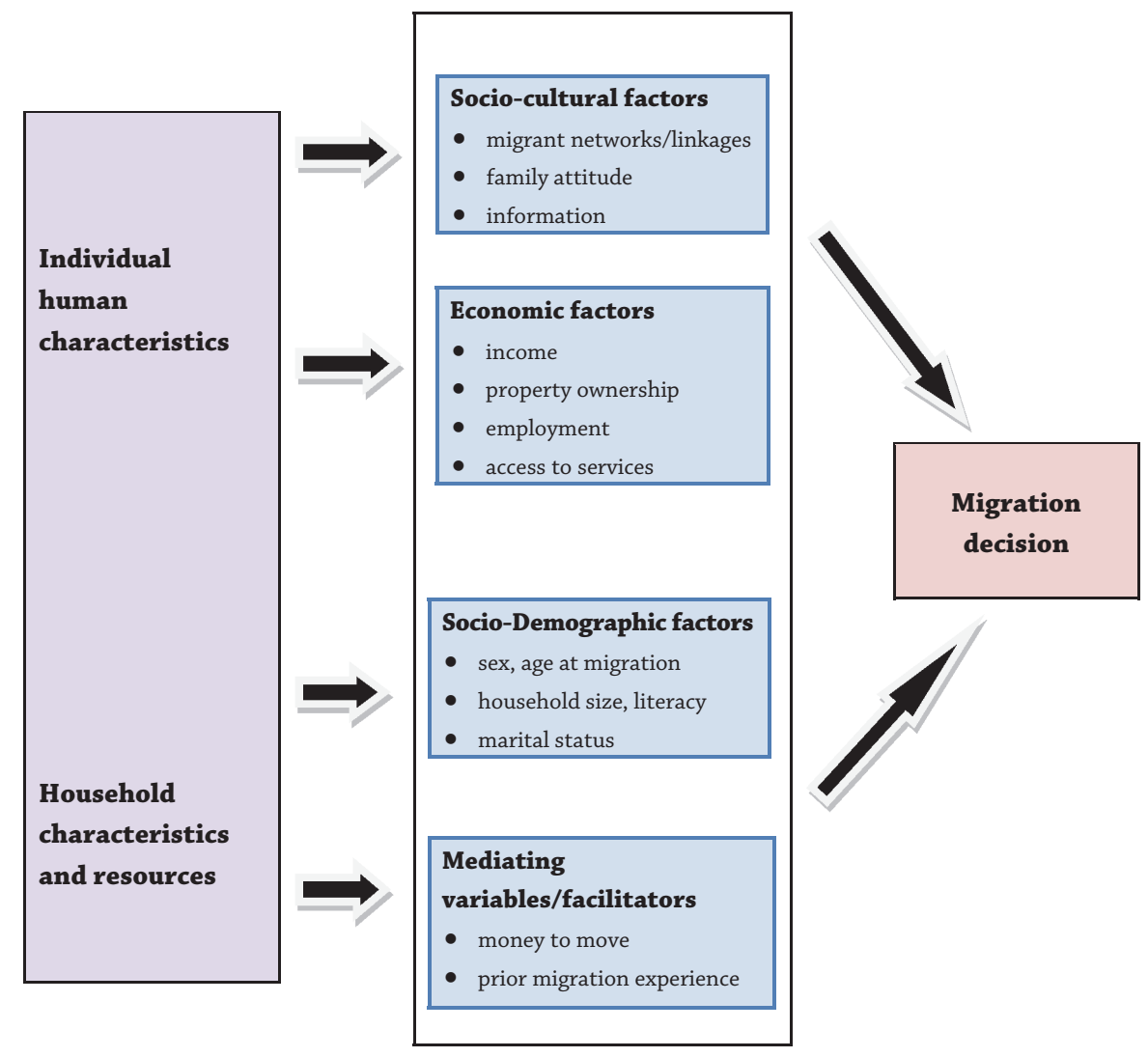

Fig. 1. Conceptual framework of the study (De Jong, 2000) 


\section{Conceptual framework}

The conceptual framework in Fig. 1 was adapted from De Jong (2000). The framework depicts two groups of variables, i.e. the explanatory/independent and dependent variables. The independent variables are divided into four groups (socio-cultural factors, economic factors, socio-demographic factors \& mediating variables/facilitators). The dependent variables, on the other hand, are migration decision and remittance.

\section{Materials and methods}

\section{Data sources}

The target populations in this study were male and female residents of Dilla town who were above the age of 15; a group commonly considered as economically active. They are especially the ones who came to the study area at a certain point in time for a variety of reasons from a different part of the country. The principal data for the study were generated from primary sources using a questionnaire.

\section{Sampling design}

Dilla town has three sub cities, and each has three villages locally called "kebeles". The sample size required for this study was determined by the objective of the study, the resources available, variability of the characteristics to be measured, the precision level required, and the required confidence that the accuracy/precision is valid. A total sample of 276 was estimated (see annex) based on a formula for survey sampling design (Cochran, 1977).

The 276 study participants were selected using both purposive and systematic random sampling techniques. The process of sampling started with the listing of all kebeles in each of the three sub cities. Following preliminary discussion with the town administrators, one village from each sub city was selected using purposive sampling. The 276 respondents were proportionately divided into the three kebeles and the eligible respondents (age 15+) were selected randomly based on the household list made available by local administrators (Fig. 2).

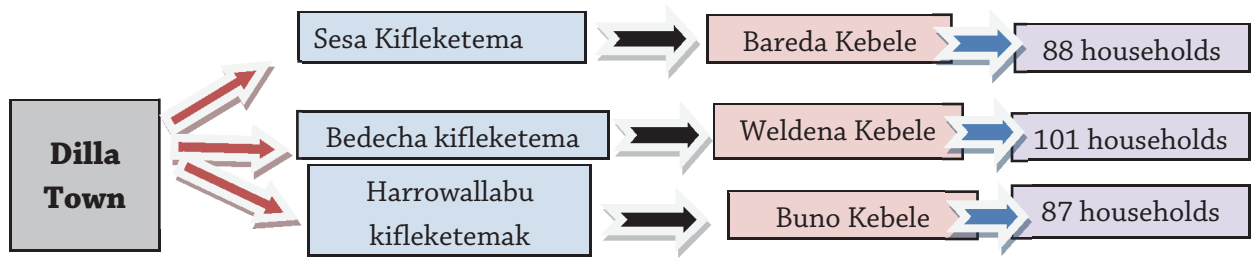

Fig. 2. Scheme for sampling design

\section{Data collection}

Data collection was done for 20 days using nine data collectors. A training session was arranged for data collectors and field supervisors. The data were edited, coded, entered into SPSS software, cleaned, processed, and made ready for analysis.

\section{Data analysis}

The data were analyzed using both bivariate and multivariate quantitative statistical tools. The gender differential in migration was analyzed using Pearson's Chi-square statistical techniques. Ordinary Least Square (OLS) regression was used to further examine the association between selected explanatory variables and remittance. Prior to building the models, the explanatory variables were vigilantly selected based on the review of literature and model building principle. Multicolinearity diagnosis was done in order to check correlations among the independent variables, and the result indicated that none of them have multicolinearity problem, which means that the VIF (variance inflation factor) value is found to be less than 4 or tolerance is found to be less than 1 .

\section{Results}

\section{Characteristics of respondents}

Table 1 shows the distribution of the respondents by selected background characteristics. Close to $60 \%$ of the migrants were males, and a great majority (93.5\%) of the participants were in the 15-64 years age group. $43.8 \%$ were Orthodox Christians, 27.2\% Protestants and 23.9\% Muslims.

The marital status prior to migration indicated that the majority (75.4\%) were single, whereas this proportion reduced significantly to $30.8 \%$ in the reports of current marital status distribution. Similarly, the percentages reporting married status increased from 21.7 to 59.4 for time before and after migration respectively. The distribution of the migrants by education level indicated that about $10 \%$ had no education, $13.8 \%$ in grades $1-6,11 \%$ were in grades $7-8,30.1 \%$ were in grades $9-12$, $21 \%$ had a college diploma, first degree and above (14.5\%).

In terms of household size, $39.1 \%$ reported to have come from households with less than three members, which is a small family size. 37\% were from households with 4-6 members (considered a medium size family), and the remaining $23.9 \%$ came from $6+$ household size. In terms of the source of migration, $39.1 \%$ of them reported their origin as 'towns/ cities', while a greater proportion $(60.9 \%)$ of them had moved from rural areas of the country.

\section{Gender differentials in migration decisions}

Table 2 presents the association between the gender of the respondents and reported reasons for migration. Two reasons seem to constitute the largest portion of the responses: looking for a job, and looking for a better life and more opportunity. These accounted for $53.6 \%$ and $58.7 \%$ respectively. Also, a considerable number of respondents (37\%) reported that they had moved to the destination because of other problems faced at the place of origin. On the other hand, $23.6 \%$ of the migrants reported to have come to the destination because of different influences at the place of origin.

As indicated in Table 2, some reasons are more important for males to migrate than they are for females. For example, problems/challenges at the place of origin are more important reasons for the males than the females. In the same way, the 
Table 1. Percentage distribution of migrants by selected socio-demographic characteristics, Gedeo Zone $(n=276)$

\begin{tabular}{|c|c|c|}
\hline Characteristics & Number & Percent \\
\hline \multicolumn{3}{|l|}{ Sex } \\
\hline female & 113 & 40.9 \\
\hline male & 163 & 59.1 \\
\hline \multicolumn{3}{|l|}{ Age at migration } \\
\hline $0-15$ years & 18 & 6.5 \\
\hline $15-64$ years & 258 & 93.5 \\
\hline above 64 & 0 & 0.0 \\
\hline \multicolumn{3}{|c|}{ Marital status prior to migration } \\
\hline divorced/separated & 8 & 2.9 \\
\hline single & 208 & 75.4 \\
\hline married & 60 & 21.7 \\
\hline \multicolumn{3}{|l|}{ Current marital status } \\
\hline divorced/separated & 11 & 4.0 \\
\hline single & 85 & 30.8 \\
\hline widowed & 16 & 5.8 \\
\hline married & 164 & 59.4 \\
\hline \multicolumn{3}{|l|}{ Religion } \\
\hline orthodox & 121 & 43.8 \\
\hline catholic & 10 & 3.6 \\
\hline protestant & 75 & 27.2 \\
\hline islam & 66 & 23.9 \\
\hline traditional & 1 & 0.4 \\
\hline others & 3 & 1.1 \\
\hline \multicolumn{3}{|l|}{ Level of education } \\
\hline illiterate & 27 & 9.8 \\
\hline elementary (1-6) & 38 & 13.8 \\
\hline junior secondary (7 \& 8) & 30 & 10.9 \\
\hline secondary (9-12) & 83 & 30.1 \\
\hline college diploma & 58 & 21.0 \\
\hline first degree $\&$ above & 40 & 14.5 \\
\hline \multicolumn{3}{|l|}{ Household size } \\
\hline $1-3$ & 108 & 39.1 \\
\hline $4-6$ & 102 & 37.0 \\
\hline above 6 & 66 & 23.9 \\
\hline \multicolumn{3}{|l|}{ Place of birth } \\
\hline town/city & 108 & 39.1 \\
\hline countryside & 168 & 60.9 \\
\hline
\end{tabular}

search for a job appeared to be a more significant reason for the males than for the females. On the other hand, marriage seems to be a more important reason for females to migrate than for males. Also, more females than males migrate due to their desire for better income, job opportunity and related factors.

Table 3 presents the results of bivariate analysis (using chi square) on gender differentials in migration decision. It is noted that family decision in migration was important to an almost equal proportion of females and males $(51.1 \%$ and $50.3 \%$ respectively). On the other hand, a considerable proportion of both females and males $(66.4 \%$ and $73.0 \%$ respectively) reported they themselves made the decision to migrate. Migration decision due to other factors contributed only a small proportion for both sexes.

About $45 \%$ of females and $33 \%$ of males reported to have obtained the money they required to move from their family. An insignificant proportion of females (5.3\%) and $24.5 \%$ of males reported that they received financial support from their relatives when they first moved to the place of destination. The results of Chi-square analysis confirmed the association between gender and source of money for the migrants' first move. More females than males were able to get the money from their spouse. On the other hand, more males than females claimed that relatives were their main source of funding when they first moved.

With respect to family attitude towards migration decision, an almost equal proportion of both females and males $(57.5 \%$ and $58.3 \%$ respectively) reported that they had received encouragement from their families. A quarter of both female and male respondents indicated experiencing unfavorable attitudes from their families about their migration decision. Close to $17 \%$ reported that they had not been sure about the attitude their family members had about their migration decision.

An almost equal proportion of both females and males ( $20.4 \%$ and $19.6 \%$ respectively) reported that they initially intended to stay in Dilla as a temporary resident. On the other hand, $40.1 \%$ of the females and $50.4 \%$ of the males intended to stay permanently. A significant proportion of the respondents (about 35\%) were not sure whether to stay temporarily or permanently.

Table 2. Results of Chi-square analysis for association between gender and reported reasons for migration, Gedeo Zone $(n=276)$

\begin{tabular}{|c|c|c|c|c|c|}
\hline Reasons for migration & Category & Female (\%) & Male (\%) & Total (\%) & Chi-square $\left(\chi^{2}\right)$ \\
\hline \multirow{2}{*}{ problems/ challenges } & yes & 18.6 & 49.7 & 37.0 & \multirow{2}{*}{$\begin{array}{c}27.721 \\
(P=0.000)^{c}\end{array}$} \\
\hline & no & 81.4 & 50.3 & 63.0 & \\
\hline \multirow{2}{*}{ job search } & yes & 38.9 & 63.8 & 53.6 & \multirow{2}{*}{$\begin{array}{c}16.592 \\
(P=0.000)^{c}\end{array}$} \\
\hline & no & 61.1 & 36.2 & 46.4 & \\
\hline \multirow{2}{*}{ service problems } & yes & 14.2 & 21.5 & 18.5 & \multirow{2}{*}{$\begin{array}{c}2.369 \\
(P=0.124)\end{array}$} \\
\hline & no & 85.8 & 78.5 & 81.5 & \\
\hline \multirow{2}{*}{ to be free from influences } & yes & 18.6 & 27.0 & 23.6 & \multirow{2}{*}{$\begin{array}{c}2.622 \\
(P=0.105)\end{array}$} \\
\hline & no & 81.4 & 73.0 & 76.4 & \\
\hline \multirow{2}{*}{ for meeting a person in Dilla } & yes & 16.8 & 19.6 & 18.5 & \multirow{2}{*}{$\begin{array}{c}0.352 \\
(P=0.553)\end{array}$} \\
\hline & no & 83.2 & 80.4 & 81.5 & \\
\hline \multirow{2}{*}{ for education/training } & yes & 24.8 & 15.3 & 19.2 & \multirow{2}{*}{$\begin{array}{c}3.834 \\
(P=0.050)^{\mathrm{a}}\end{array}$} \\
\hline & no & 75.2 & 84.7 & 80.8 & \\
\hline \multirow{2}{*}{ for making use of services in town } & yes & 8.0 & 11.0 & 9.8 & \multirow{2}{*}{$\begin{array}{c}0.717 \\
(P=0.397)\end{array}$} \\
\hline & no & 92.0 & 89.0 & 90.2 & \\
\hline
\end{tabular}


Table 2. (Continued)

\begin{tabular}{|c|c|c|c|c|c|}
\hline Reasons for migration & Category & Female (\%) & Male (\%) & Total (\%) & Chi-square $\left(\chi^{2}\right)$ \\
\hline \multirow{2}{*}{ job transfer } & yes & 11.5 & 16.0 & 14.1 & \multirow{2}{*}{$\begin{array}{c}1.087 \\
(P=0297)\end{array}$} \\
\hline & no & 88.5 & 84.0 & 85.9 & \\
\hline \multirow{2}{*}{ for starting/enlarging private business } & yes & 5.3 & 13.5 & 10.1 & \multirow{2}{*}{$\begin{array}{c}4.907 \\
(P=0.027)^{\mathrm{a}}\end{array}$} \\
\hline & no & 94.7 & 86.5 & 89.9 & \\
\hline \multirow{2}{*}{ looking for comfortable climate } & yes & 5.3 & 7.4 & 6.5 & \multirow{2}{*}{$\begin{array}{c}0.461 \\
(P=0.497)\end{array}$} \\
\hline & no & 94.7 & 92.6 & 93.5 & \\
\hline \multirow{2}{*}{ any kind(s) of harassment/abuse } & yes & 8.0 & 9.2 & 8.7 & \multirow{2}{*}{$\begin{array}{c}0.129 \\
(P=0.720)\end{array}$} \\
\hline & no & 92.0 & 90.8 & 91.3 & \\
\hline \multirow{2}{*}{ previous experience in the town } & yes & 6.2 & 11.7 & 9.4 & \multirow{2}{*}{$\begin{array}{c}2.333 \\
(P=0.127)\end{array}$} \\
\hline & no & 93.8 & 88.3 & 90.6 & \\
\hline \multirow{2}{*}{ marriage } & yes & 32.7 & 4.9 & 16.3 & \multirow{2}{*}{$\begin{array}{c}37.892 \\
(P=0.000)^{c}\end{array}$} \\
\hline & no & 67.3 & 95.1 & 83.7 & \\
\hline \multirow{2}{*}{$\begin{array}{l}\text { motive for better income, job opportunity, } \\
\text { etc. }\end{array}$} & yes & 74.3 & 47.9 & 58.7 & \multirow{2}{*}{$\begin{array}{c}19.307 \\
(P=0.000)^{c}\end{array}$} \\
\hline & no & 25.7 & 52.1 & 41.3 & \\
\hline
\end{tabular}

Table 3. Results of Chi-square analysis for association between gender and selected variables, Gedeo Zone $(\boldsymbol{n}=276)$

\begin{tabular}{|c|c|c|c|c|c|}
\hline Variables & Category & Female (\%) & Male (\%) & Total (\%) & Chi-square $\left(\chi^{2}\right)$ \\
\hline \multirow{2}{*}{ migration decision by family } & yes & 53.1 & 50.3 & 51.4 & \multirow{2}{*}{$\begin{array}{c}0.208 \\
(P=0.648)\end{array}$} \\
\hline & no & 46.9 & 49.7 & 48.6 & \\
\hline \multirow{2}{*}{ migration decision by self } & yes & 66.4 & 73.0 & 70.3 & \multirow{2}{*}{$\begin{array}{c}1.407 \\
(P=0.236)\end{array}$} \\
\hline & no & 33.6 & 27.0 & 29.7 & \\
\hline \multirow{2}{*}{ migration decision by employer } & yes & 6.2 & 9.8 & 8.3 & \multirow{2}{*}{$\begin{array}{c}1.146 \\
(P=0.284)\end{array}$} \\
\hline & no & 93.8 & 90.2 & 91.7 & \\
\hline \multirow{2}{*}{ migration decision by relative } & yes & 10.6 & 12.9 & 12.0 & \multirow{2}{*}{$\begin{array}{c}0.325 \\
(P=0.569)\end{array}$} \\
\hline & no & 89.4 & 87.1 & 88.0 & \\
\hline \multirow{6}{*}{ source of money required to move } & family & 45.1 & 32.5 & 37.7 & \multirow{6}{*}{$\begin{array}{c}63.323 \\
(P=0.000)^{c}\end{array}$} \\
\hline & relative & 5.3 & 24.5 & 16.7 & \\
\hline & friend & 0.9 & 1.2 & 1.1 & \\
\hline & spouse & 23.0 & 0.0 & 9.4 & \\
\hline & borrowed & 1.8 & 9.8 & 6.5 & \\
\hline & self & 23.9 & 31.9 & 28.6 & \\
\hline \multirow{2}{*}{ nature of migration decision } & planned & 65.5 & 54.6 & 59.1 & \multirow{2}{*}{$\begin{array}{c}3.270 \\
(P=0.071)\end{array}$} \\
\hline & unplanned & 34.5 & 45.4 & 40.9 & \\
\hline \multirow{3}{*}{ family attitude towards migration decision } & discouraging & 25.7 & 25.2 & 25.4 & \multirow{3}{*}{$\begin{array}{c}0.016 \\
(P=0.892)\end{array}$} \\
\hline & encouraging & 57.5 & 58.3 & 58.0 & \\
\hline & not sure & 16.8 & 16.6 & 16.7 & \\
\hline \multirow{3}{*}{ nature of stay in place of destination } & temporarily & 20.4 & 19.6 & 19.9 & \multirow{3}{*}{$\begin{array}{c}0.022 \\
(P=0.989)\end{array}$} \\
\hline & permanently & 45.1 & 45.4 & 45.3 & \\
\hline & not sure & 34.5 & 35.0 & 34.8 & \\
\hline
\end{tabular}




\section{Determinants of remittance: multivariate analysis}

Table 4 presents the effects of selected variables on remittance. It is seen that sex and current marital status of respondents affect frequency of remittance; where more females than males remit frequently. Moreover, employment is found to be statistically significant $(p=0.003)$. Similarly, other variables like average monthly income \& communication of migrants with their place of origin were also found to significantly affect frequency of remittance.

Table 4. Results of Linear regression for selected explanatory variables and frequency of remittance back to place of origin, Gedeo Zone $(n=276)$

\begin{tabular}{|c|c|c|c|c|}
\hline \multirow{2}{*}{$\begin{array}{l}\text { Variables } \\
\text { (constant) }\end{array}$} & \multirow[b]{2}{*}{$\beta 2.717$} & \multirow[b]{2}{*}{ Std. Error 0.767} & \multicolumn{2}{|c|}{ Coefficients } \\
\hline & & & $\beta$ & Sig. 0.000 \\
\hline sex of the respondent & -0.284 & 0.169 & -0.103 & 0.094 \\
\hline current marital status & 0.154 & 0.092 & 0.115 & 0.094 \\
\hline level of formal education attained & -0.041 & 0.055 & -0.047 & 0.453 \\
\hline household size & -0.140 & 0.125 & -0.081 & 0.264 \\
\hline average monthly income & -0.152 & 0.054 & -0.180 & $0.006^{\mathrm{b}}$ \\
\hline communication with place of birth & 0.566 & 0.265 & 0.133 & $0.034^{\mathrm{a}}$ \\
\hline length of stay in destination & 0.093 & 0.094 & 0.075 & 0.324 \\
\hline employment & 0.820 & 0.270 & 0.208 & $0.003^{\mathrm{b}}$ \\
\hline
\end{tabular}

\section{Discussion}

This study was primarily aimed at assessing the gender differentials in migration based on 276 respondents from Dilla town in Southern Ethiopia. The result suggested that migration to the town is age selective; more than $90 \%$ of the migrants moved to the town at younger age. This is consistent with previous studies which reported that the vast majority of migrants in other populations are concentrated in the young adult age-group of 20-30 years (Caldwell, 1969; Clark, 1986; Goldstein, 1976; Jansen, 1970; O’Neil et al., 2016). Therefore, it is also not a surprise that many of them were single at the time of arrival.

The analysis also suggested the presence of a great deal of gender differences in several domains of migration, especially at the place of destination. With regard to the gender difference in reported reasons for migration decision, four factors became significantly associated with gender. These were challenges at the place of origin, job search, desire for better income and job opportunity, and marriage $(p<0.001)$. This is in line with O'Neil et al. (2016) who reported that people migrate to overcome poverty, escape conflict, or cope with economic and environmental shocks. They also indicated that gender norms affect when and why people migrate. More males than females reported problems/challenges at the place of origin and job seeking as the main reasons.

On the other hand, more female migrants than men reported marriage and desire for a better life in urban areas as their prime reasons. The greater values associated with marriage among women in most societies of Ethiopia may explain why more women than men would report marriage as a major cause of migration (Djamba, 2003). In Ghana, for instance, earning money to buy the goods needed to make a good marriage is a key motivator of migration for both boys and girls migrating in their early to late teenage years. While boys have more opportunities for employment and migration, parents are also very accepting of girls' migration because girls traditionally move to their husband's family upon marriage
(Hashim, 2005). In some settings, older daughters will migrate to allow younger siblings to attend school. In countries such as the Philippines and Sri Lanka, migration may be considered more acceptable than divorce (Afsar, 2009). Women experiencing gender-based violence, domestic abuse, unhappy marriage, or a lack of appropriate employment opportunities may also be more inclined to migrate (Afsar, 2009; Petrozziello, 2013). It is also interesting to note that more females migrated for better education, while more males migrated for business. Similarly, other studies (Avellan, 2003; Cerrutti and Massey, 2001) noted that while adult men move for employment, adult women migrate for family reasons.

We noted significant bivariate association between gender and the source of money required to migrate. More females than males reported obtaining the money they required to move from their spouses and families. This strengthens the idea that women's migration is based more on a household decision than individual needs. The finding is consistent with previous studies (O'Neil et al., 2016) who reported that women usually have less control over the decision to migrate than men - a decision more likely to be taken by their family. Several studies of internal Filipino migrants show that families are more likely to send daughters to migrate because they perceive them to be more reliable in sending remittances (Piper, 2005; Jolly and Reeves, 2005). O'Neil et al. (2016) supported this idea; reporting that women remit a higher proportion of their incomes than male migrants. This further strengthens the idea that females are more dependable in terms of supporting their family members through remittance. In relation to this, studies conducted in other parts of the world confirmed that women are more likely than men to return home suddenly when they hear of a developing crisis in the family, e.g. husband's infidelity, neglect of children, children's drug abuse or family mismanagement of remittances (Villalba, 2002).

The OLS regression indicated a positive relationship between remittance and gender, where more females than males send money to their families more often. Migration may be the only option for women in the face of family poverty, or the best option for personal or family betterment. The desire 
is often to send remittances - money earned or acquired by immigrants that is sent back home to their country of origin (Jolly and Reeves, 2005). A study in Nicaragua and Costa Rica reported that nine out of ten women send money home, while only six out of 10 men do.

Finally, this study is not without limitation. Since the research is a cross sectional retrospective, the probability of recall bias and misreporting of migration related events are likely to happen. Besides, the variables used in the analysis were collected at a specific point in time, making it difficult to link their effects with the outcome variable. However, this piece of work contributes to our understanding of how the migration of men and women is shaped by a combination of individual and household decisions.

\section{Conclusions}

On the basis of the information collected from the $276 \mathrm{mi}$ grants and taking into account the methodological pitfalls of studying migration, this study has concluded that there are significant gender differentials with respect to migration decisions and remittance. It is generally noted that women's migration is more of a household decision determined by a household livelihood strategy such as poverty reduction, better education for household members and marriage. It appeared that more females than males send remittance to their place of origin.
Given the fact that internal migration of this kind has both positive and negative repercussions at the place of origin, the findings of the study suggests the need for in-depth investigation of the positive roles of migration sex-age selective migration on the place of origin.

\section{Annex}

Sample size estimation (Cochrane, 1977):

$n=\left(\frac{z}{d}\right)^{2} p(1-p)$

$n$ = sample size;

$\mathrm{z}=$ values of standard variant at $95 \%$ confidence interval $(t=1.96)$;

$p=$ the estimated value for the proportion of a sample that will choose a given answer to a survey question (in this case, $p=0.15)$;

$d$ = acceptable margin of error for proportion being estimated $(d=0.05)$.

Therefore, the sample size was computed as:

$n=\left(\frac{1.96}{.05}\right)^{2} 0.15(1-.5)+10 \%$ contingency $=276$

\section{Conflict of interest}

The authors have no conflict of interest to declare.

\title{
Genderové rozdíly ovlivňující rozhodnutí o vnitřní migraci ve městě Dilla v jižní Etiopii
}

\begin{abstract}
Souhrn
Úvod: Vnitřní migrace se v Etiopii, v návaznosti na nové ekonomické a sociální uspořádání od roku 1991, stává stále důležitějším socioekonomickým fenoménem. Primárním cílem této studie bylo zjistit, jak gender ovlivňuje rozhodnutí o migraci, a to s pomocí dat získaných ve městě v jižní Etiopii.

Metody: Ve studii byla použita data získaná od 216 náhodně vybraných domácností ze tři městských částí ve městě Dilla. Pro zkoumání genderových rozdílů ovlivňujících rozhodnutí o migraci byl použit chí-kvadrátový test a multivariační analýza (logistická regrese).

Výsledky: Analýza ukázala, jak důležité jsou genderové rozdíly ovlivňující rozhodnutí o migraci; rozhodnutí o migraci je určeno genderem a věkem $(\mathrm{p}<0,05)$. Migraci plánují více ženy než muži $(p<0,001)$. Zatímco muži migrují převážně kvůli ekonomickým problémům, ženy migrují kvůli rodinným záležitostem $(p<0,001)$. Za možností vzdělání migrují více ženy, za možností práce muži. Zdá se, že migrace žen má pozitivnější vliv na místo jejich původní domácnosti, nebot́ jí zasílají část svých př́immů. Z multivariační analýzy vyplývají tři faktory, které mají významný vliv na zasílání zdrojů do domácnosti $(p<0,05)$ : pravidelná komunikace, zaměstnání a výše př́imu.

Závěr: Záměry a důvody ovlivňující rozhodnutí o migraci se mezi muži a ženami velmi liší; ženy se o migraci rozhodují déle a více ji plánují. Studie implikuje potřebu dalšího hlubšího zkoumání vnitřní migrace ovlivněné genderem a věkem.
\end{abstract}

Klíčová slova: determinanty rozhodování; rozdílnosti; gender; migrace; zasílání přímů

\section{References}

1. Afsar R (2009). Unravelling the vicious cycle of recruitment: Labor migration from Bangladesh to the Gulf states. Working paper 63. Geneva: International Labor Office.

2. Avellan H (2003). Cuanto gané, cuanto perdí? - Hombres y Hogares en tiempos de migración [You win some, you lose some - Men and the home in times of migration]. Managua: Impresiones Helios, S.A.

3. Awumbila M (2015). Women moving within borders: gender and internal migration dynamics in Ghana. Ghana Journal of Geography 7(2): 132-145.
4. Awumbila M (2017). Drivers of migration and urbanization in Africa: key trends and issues. [online] [cit. 2018-05-13]. Available from: https://www.un.org/en/development/desa/ population/events/pdf/expert/27/papers/III/paper-Awunbilafinal.pdf

5. Boyd M, Grieco E (2003). Women and migration: incorporating gender into international migration theory. [online] [cit. 201805-13]. Available from: http://www.migrationinformation.org/ Feature/print.cfm?ID=106

6. Caldwell JC (1969). African rural-urban migration: the movement to Ghana's towns. New York: Columbia Univ. Press.

7. Camlin CS, Snow RC, Hosegood V (2013). Gendered patterns of migration in rural South Africa. Population, Space and Place 20(6): 528-551. DOI: 10.1002/psp.1794. 
8. Cattaneo $C$ (2007). The self-selection in the migration process: what can we learn? Liuc Papers in Economics 199(52).

9. Cerutti M, Massey DS (2001). On the auspicies of femal migration from Mexico to the United States. Demography 38(2): 187-200. DOI: 10.1353/dem.2001.0013.

10. Clark AV (1986). Human migration. Beverly Hills: SAGE Publications.

11. Cochran WG (1977). Sampling techniques, 3rd ed. New York: John Wiley \& Sons.

12. Curran SR, Saguy AC (1997). Migration and cultural change: a role for gender and social networks? Journal of International Women's Studies 2(3): 54-77.

13. De Jong GF (2000). Expectations, gender, and norms in migration decision-making. Popul Stud 54(3): 307-319. DOI: $10.1080 / 713779089$.

14. De Jong GF, Richter K, Isarabhakdi P (1996). Gender, values, and intentions to move in rural Thailand. Int Migr Rev 30(3): 641-664. DOI: $10.2307 / 2547635$.

15. Deshingkar P (2005). Maximizing the benefits of internal migration for development. Background paper prepared for the Regional Conference on Migration and Development in Asia. Lanzhou, China, 14-16 March 2005. [online] [cit. 2018-05-13]. Available from: https://www.odi.org/sites/odi.org.uk/files/odiassets/publications-opinion-files/2358.pdf

16. Djamba YK (2003). Gender differences in motivations and intentions for move: Ethiopia and South Africa compared. Genus 59(2): 93-111.

17. Donato KM (1993). Current trends and patterns of female migration: Evidence from Mexico. Int Migr Rev 27(4): 748-771. DOI: $10.2307 / 2546911$.

18. El Jack A (2003). Gender and armed conflict. Overview Report. Brighton: BRIDGE/Institute of Development Studies.

19. Ezra M, Kiros GE (2001). Rural out-migration in the droughtprone areas of Ethiopia: a multi-level analysis. Int Migr Rev 35(3): 749-771.

20. Fransen S, Kuschminder K (2009). Migration in Ethiopia: history, current trends and future prospects. Paper Series: migration and development country profiles. [online] [cit. 201805-13]. Available from: mgsog.merit.unu.edu/ISacademie/docs/ CR_ethiopia.pdf

21. Goldstein S (1976). Migration and urban growth in Thailand. In Kubat D (Ed.). Internal migration: the new world and the third world. Beverly Hills: SAGE Publications.

22. Gurmu E (2005). Fertility Transition Driven by Poverty: The Case of Addis Ababa (Ethiopia). A PhD Thesis, University of London, England.

23. Hashim IM (2005). Research Report on Children's Independent Migration from Northeastern to Central Ghana. [online] [cit. 2018-05-13]. Available from: https://childhub.org/fr/system/ tdf/library/attachments/hashim_05_child_mig_north_0408. pdf?file $=1$ \&type $=$ node\&id $=18160$

24. International Organization for Migration (IOM) (2013). Taking action against violence and discrimination affecting migrant women and girls. [online] [cit. 2018-05-13]. Available from: https://publications.iom.int/system/files/pdf/violence_against_ women_infosheet2013.pdf

25. Jansen CJ (1970). Readings in the sociology of migration. Oxford: Pergman Press.

26. Jolly S, Reeves H (2005). Gender and migration. Brighton: Institute of Development Studies.

27. Lattes AE (1989). Emerging pattern of territorial mobility in Latin - America: challenges for research and action.
International Population Conference, Vol. 1. New Delhi: International Union for Scientific Study of Population.

28. Massey DS (1998). Worlds in motion: Understanding international migration at the end of the millennium. Oxford: Clarendon Press.

29. McBride PJ (1991). Human geography: systems, patterns and change. 3rd ed. London: Blackie and Son Ltd.

30. Morrissey J (2007). Rural-urban migration in Ethiopia. [online] [cit. 2018-05-13]. Available from: https://www.fmreview.org/ sites/fmr/files/FMRdownloads/en/climatechange/morrissey. pdf

31. Muru M (2008). Globalization, migration and brain drain: a reality check. Globalization, migration and brain drain: a reality check 6(3): 153-163.

32. O'Neil T, Fleury A, Foresti M (2016). Women on the move: migration, gender equality and the 2030 Agenda for Sustainable Development. [online] [cit. 2018-05-13]. Available from: https://www.odi.org/publications/10476-women-movemigration-gender-equality-and-2030-agenda-sustainabledevelopment

33. Omelaniuk I (2005). Gender, poverty reduction and migration. Washington DC: World Bank.

34. Peri G (2016). Immigrants, productivity, and labor markets. J Econ Perspect 30(4): 3-30. DOI: 10.1257/jep.30.4.3.

35. Petrozziello AJ (2013). Gender on the move: working on the migration-development nexus from a gender perspective. Santo Domingo: UN Women.

36. Piper N (2005). Gender and migration. Background paper for Global Commission on International Migration (GCIM) and appendix to the GCIM Global Report on Migration, Recommendations to the Secretary General.

37. Regassa N, Yusufe A (2011). Gender differentials in migration impacts in Southern Ethiopia. The Antropologist 11(2): 129-137. DOI: 10.1080/09720073.2009.11891092.

38. Tacoli C, McGranahan G, Satterthwaite D (2015). Urbanization, rural-urban migration and urban poverty. Working paper. London: IIED.

39. Tadele F, Pankhurst A, Bevan P, Lavers T (2006). Migration and rural-urban linkages in Ethiopia: case studies of five rural and two urban sites in Addis Ababa, Amhara, Oromia and SNNP Regions and Implications for Policy and Development Practice. Paper prepared for Irish Aid-Ethiopia. ESRC WeD Research Program. United Kingdom: University of Bath.

40. Todaro M P (1976). Internal migration in developing countries: a review of theory evidence, methodology and research priorities. Geneva: International Labour Office.

41. UNICEF (2017). Internal migration and gender. [online] [cit. 2018-04-21]. Available from: https://www.unescogym.org/wpcontent/uploads/2015/06/5_Internal-Migration-and-Gender Artwork.pdf

42. United Nations (1984). Concise Report on the world population situation in 1983 - conditions, trends, prospects, policies. New York: United Nations.

43. Villalba MA (2002). Philippines: good practices for the protection of Filipino women migrant workers in vulnerable jobs. GENPROM Working Paper 8. Geneva: International Labour Office. Gender Promotion Programme.

44. World Bank (2011). International migration and development brief. [online] [cit. 2018-05-13]. Available from: https://siteresources.worldbank.org/ INTPROSPECTS/Resources/334934-1288990760745/ MigrationandDevelopmentBrief22.pdf 